DOI: https://doi.org/10.34069/AI/2021.37.01.7

\title{
Social and legal nature of bullying
}

\section{Соціально-правова природа булінгу}

\section{Naturaleza sociojurídica del acoso escolar}

\author{
Written by: \\ Shablystyi Volodymyr ${ }^{22}$ \\ https://orcid.org/0000-0003-0210-1772 \\ Obrusna Svitlana ${ }^{23}$ \\ https://orcid.org/0000-0001-9354-9235 \\ Levchenko Yuriy ${ }^{24}$ \\ https://orcid.org/0000-0003-1124-9517 \\ Gluhoverya Vitaliy ${ }^{25}$ \\ https://orcid.org/0000-0002-0864-8114 \\ Rufanova Viktoriia ${ }^{26}$ \\ https://orcid.org/0000-0002-1125-6277
}

\begin{abstract}
The aim of the article is to analyze the concepts of bullying and mobbing, to determine their social and legal nature, to formulate our own definition of these terms. The subject of the study is an analysis of the concepts of bullying and mobbing. The research methodology includes the following methods: system and structural method, formal and dogmatic method, historical method, clustering method, comparative and legal method, legal modeling method and others. The results of the study. The definition of bullying is comprehensively studied, its types are singled out, the phases of its development are determined. Practical implication. The difference between bullying and mobbing, as well as between bullying and conflict, is studied. Value / originality. Based on the research conducted the authors' concepts of bulling and mobbing are proposed.
\end{abstract}

Key Words: bullying, violence, harassment, phases of bullying development, mobbing.

\begin{abstract}
Анотація
Метою статті $є$ аналіз поняття булінгу та мобінгу, визначення їх соціальної та правової природу, формулювання власного визначення цих термінів. Предметом дослідження $є$ аналіз понять булінгу та мобінгу. Методологія дослідження включає такі методи: системноструктурний метод, формально-догматичний метод, історичний метод, метод групування, порівняльно-правовий метод, метод правового моделювання та інші. Результати дослідження. Усебічно досліджується поняття боулінгу, виокремлюються його види, визначаються фази його розвитку. Практичне значення. Вивчається різниця між булінгом та мобінгом, а також між булінгом та конфліктом. Цінність / оригінальність. На основі проведеного дослідження запропоновано авторські визначення булінгу та мобінгу.
\end{abstract}

Ключові слова: булінг, насильство, знущання, фази розвитку булінгу, мобінг.

\footnotetext{
${ }^{22}$ Doctor of Law, Professor, Professor of the Department of Criminal Law and Criminology of Dnipropetrovsk State University of Internal Affairs.

${ }^{23}$ Doctor of Law, Associate Professor, Professor of the Department of State and Legal Disciplines of Bohdan Khmelnytsky National University of Cherkasy.

${ }^{24} \mathrm{PhD}$ in Law, Associate Professor, Head of the Department of Criminology and Criminal Enforcement of the National Academy of the Affairs.

${ }^{25}$ Doctor of Law, Honored Lawyer of Ukraine, Vice-Rector of Dnipropetrovsk State University of Internal Affairs, Ukraine.

${ }^{26} \mathrm{PhD}$ in Law, Senior Lecturer of the Department of Criminal Law and Criminology of Dnipropetrovsk State University of Internal Affairs, Ukraine.
} 


\section{Resumen}

El objetivo del artículo es analizar los conceptos de bullying y mobbing, determinar su naturaleza social y jurídica, para formular nuestra propia definición de estos términos. El tema del estudio es un análisis de los conceptos de bullying y mobbing. La metodología de investigación incluye los siguientes métodos: método de sistema y estructural, método formal y dogmático, método histórico, método de agrupamiento, método comparativo y legal, método de modelado legal y otros. Los resultados del estudio. La definición de acoso escolar se estudia de manera integral, se destacan sus tipos, se determinan las fases de su desarrollo. Implicación práctica. Se estudia la diferencia entre bullying y mobbing, así como entre bullying y conflicto. Valor / originalidad. A partir de la investigación realizada, se proponen los conceptos de los autores sobre acoso y acoso.

Palabras clave: bullying, violencia, acoso, fases de desarrollo del bullying, mobbing.

\section{Introduction}

Violence has a long history, beginning with the emergence of a man and society, property classes and states. According to the Lamentations of Jeremiah and the laws of the Sumerians, children were subjected to various forms of violence in the Ancient East. Thus, killing a newborn was seen as the only solution to reduce the number of children. Today, this act of violence is considered a crime, but during the emergence and existence of the slave formation it was a common method of preventing high birth rates by physically destroying a defenseless creature. (Buchner 2001, p. 74).

In different areas of knowledge, attention is focused on various aspects of violence. Thus, jurisprudence stresses on the violation of legal norms; sociology identifies the causes and prevalence of violence as a social deviation and defines it as a phenomenon of discrimination against individuals and families, oppression or restriction of their rights and freedoms. Violence can be considered as an illegal act that brings much more profit than legitimate activities in one area or another from the standpoint of economics. Philosophy defines violence as the use of force or the threat of its use; as making force the law of human relations.

Among the types of violence are: individual and collective violence; explicit and implicit (hidden); real and imaginary; one-time, repeated, lasting for years, etc.

Thus, the concept of violence is considered by the scientists in different ways in various areas of knowledge: from a narrow concept inflicting physical harm on another person to a comprehensive category - the oppression of human rights. Violence can take many forms, from nicknames and insults to murder. There is no measure of violence, but it is increasing. It is universal. Its object can be any person and any family regardless of their social status, standard of living, place of residence.

Thus, the purpose of the research is to explore the concept, content and essence of bullying. To achieve this goal, the following tasks were performed: the definition of bullying is provided, its social and legal nature is analyzed, the types of bullying are identified, and the concept of mobbing was considered separately.

\section{Methodology}

In order to achieve the aim of the Article, the following methods of scientific knowledge are used. Monographic method helped in the study of the views of different scholars on the concepts of bulling and mobbing. The methods of analysis and synthesis enabled to determine the features, types and forms of bulling and mobbing. System and struclural method allowed to divide bullying into subspecies based on relevant features. Statistical method was useful when considering the current state of bulling in Ukraine and worldwide. Abstract and logical method was used to formulate the authors' views on the concepts of bulling and mobbing.

\section{Literature Review}

The problem of bullying in Ukraine is just beginning to be studied. Domestic research is usually carried out in the area of pedagogy and psychology and is based on foreign developments in the theory of bullying.

At the same time, foreign scholars have considered this problem for a long time. There are many definitions of this phenomenon in the relevant scientific literature. For example, Randall (2001, p. 115) defines bullying as "a social interaction within which one person 
(sometimes several persons) is attacked by another person (sometimes several persons, but usually no more than four) almost daily for a long period of time (several months), which causes a state of helplessness of a victim and his (her) exclusion from the group.

Morozov (2010, pp. 262 - 263) defines bullying as aggressive persecution of one of the team members by other team members or by a part of it.

Ponomarev (2013, p. 126), studying the phenomenon of bullying, note that such aggressive behavior can be manifested in both physical and psychological or combined (physical and psychological) violence. Besides, he states that such actions are committed for a specific purpose.

Oudmayer (2016, p. 39) understands bullying as an aggressive behavior of one person towards another one in order to cause moral or physical harm to the latter, to humiliate and thus assert his power.

Lane (2001, p. 240) defines bullying as longterm physical or mental violence by one individual or group of individuals against another individual who is unable to defend himself (herself) in the situation.

Norwegian psychologist Olweus (1993, p. 28) provided a common definition of bullying among children and adolescents, which is a deliberate, systematically repeated aggressive behavior based on inequality of social power or physical strength.

The aim of our research is to propose our own concept of bulling based on the works of foreign and domestic scientist in this sphere.

\section{Results and Discussion}

Research on the problem of such form of violence as bullying began relatively recently, in the $60 \mathrm{~s}$ and $70 \mathrm{~s}$ of the $20^{\text {th }}$ century, when society began to contemplate the existence of a link between the phenomena of deviant and aggressive behavior in society and the way people are brought up, grow and learn during school years, began to realize the importance of studying the causes and consequences of this phenomenon in order to have leverage and control over the situation. Studies show that bullying can be considered the first step towards real violence and criminal behavior. Thus, $60 \%$ of those identified as offenders in grades $6-9$ had at least one conviction before the age of 24 , and $35-40 \%$ had committed three or more serious offences when they reached the age of 25 (Sampson 2009, p. 49).

Violent actions, regardless of their types and forms of manifestation, can be one-time or regular. However, when violence is systematic and pursues the goal of consolidating power and authority by humiliating and devaluing another person in his (her) own eyes and those of others, the term "bullying" is used to describe this phenomenon.

The first mention of violence in children's groups dates back to the XVI century, and the first scientific publication about bullying appeared more than a hundred years ago - in 1905 (Zhebrova 2016, p. 17).

The phenomenon of school violence, or bullying, as an independent topic of scientific research appeared for the first time in the scientific works of Scandinavian scientists, who studied the nature of bullying, described the types, forms and cycle of violence, as well as developing a set of measures to prevent and reduce its prevalence.

Bullying is an international phenomenon, so it is studied by the scientists of many countries: America, Great Britain, Canada, Norway, Finland and others. Bullying has become an international socio-psychological and pedagogical term over the past 20 years, which means a complex set of social, psychological, criminological and legal problems (Ministry of Education and the Ministry of Attorney General 1999, p. 15).

According to Korol (2009, p. 87), all actions that are bullying, despite their diversity, have common features:

1) power imbalance, i.e. the perpetrator and the victim are necessarily different in social status, physical or psychological adaptation to the environment, different sex, race, religion, sexual orientation, etc .;

2) the intent to harm, i.e. the offender intentionally causes emotional or physical pain to the victim, enjoys watching his (her) sufferings;

3) the threat of further aggression, i.e. the offender and the victim understand that this is not the first one and not the last case of bullying.

On the basis of awareness of one's own actions, bullying can be divided into: 
- conscious, i.e. the perpetrator understands the seriousness of his (her) actions and their consequences;

- unconscious, i.e. the perpetrator does not perceive his (her) actions as violent, but considers them a joke or a game.

We propose to divide bullying by the number of participants into:

- one-person (individual), when one person is a bully;

- group, when acts of violence are committed by two or more persons (collective).

Bullying can also take many forms. In particular, it can be:

- $\quad$ physical - hitting, pushing, damaging or stealing property;

- $\quad$ verbal - naming, ridiculing or utterances that offend gender, race or sexual orientation;

- $\quad$ social - the exclusion of some individuals from the group or the spread of gossip or rumors;

- in writing - writing notes or signs that are painful or offensive;

- electronic (commonly known as cyberbullying) - the spread of rumors and abusive comments using e-mail, mobile phones (such as texting) and social networking sites (Tilikina 2020, p. 20).

From this perspective, bullying is divided depending on the environment where the violence takes place: real and virtual ones.

Cyberbullying (refers to a form of virtual violence) is an e-mail message that:

- used to upset, intimidate or embarrass another person;

- is done through e-mail, mobile phones, SMS and social networking sites to intimidate, harass, embarrass, socially exclude and damage reputation and friendships;

- lies in humiliation, insults and may also involve the dissemination of rumors, the disclosure of private information, photographs or videos, or contain threats of harm;

- $\quad$ is always aggressive and painful (Ministry of Education of Ontario 2013, p. 3).

There are eight types of cyberbulling:
- fights, or flaming - exchange of short angry and inflammatory remarks, using communication technologies;

- $\quad$ attacks, constant grueling attacks - most often in the form of repeated insults contained in the messages;

- slander, defamation - dissemination of humiliating false information using computer technology;

- self-knowledge - the bully positions himself as a victim, using his (her) password to access his (her) account on social networks, blog, mail, etc., and then carries out negative communication;

- fraud - obtaining personal information in interpersonal communication and its transmitting (texts, photos, videos) to the public area of the Internet;

- alienation (ostracism), isolation exclusion from the group, which exposes to serious emotional distress, up to the complete emotional destruction of the child;

- cyberbullying is the covert surveillance of persecuted persons, usually carried out secretly, anonymously, in order to organize criminal acts such as attempted rape, physical violence, and beatings;

- happy slapping - any videos that record real attacks (Tilikina 2020, p. 21).

It should be noted that this type of harassment is also dangerous because adults (parents, teachers, etc.) often cannot provide adequate assistance because they do not have the experience and knowledge of the communication in cyberspace. Therefore, children in most cases do not seek help from adults.

In Ontario schools, principals are required to respond to cyberbullying if it affects school atmosphere. That is, if a student is a victim of bullying and is embarrassed by sending e-mail of inappropriate content to other students at school, the victim may refuse to attend school. Therefore, in our opinion, bullying is unacceptable regardless of the form of manifestation.

Bullying is manifested through various forms of violence that are committed systematically against the same person, in particular:

1) Physical violence, including pushing, touching, kicks, slaps, blows and other actions that cause pain and injury, etc. 
For example, teenagers wait for a student in the yard of an educational institution and beat him because of his high academic achievements.

2) Psychological violence, including insults, spreading false rumors, ridicule, intimidation, isolation, ignoring, boycott, refusal to communicate, threats, manipulation, blackmail.

For example, a group of girls in a class discuss a weekend party and share photos, paying no attention to one girl, whom the children did not invite, pretending she did not exist. This ignorance is repeated every time.

3) Economic violence, including petty theft, damage or destruction of personal belongings, extortion, food.

For example, a twelve-year-old boy has been constantly insulted by his classmates lately. They take money from him and force him to ask his parents for money every day. He is very afraid of telling anyone about it, because older children intimidated him.

4) Sexual violence, including offensive gestures, expressions, naming, jokes, threats, spreading rumors, etc.

For example, a $6^{\text {th }}$ grade student constantly uses words with a sexual connotation, imitates sexual actions in front of other children and teachers and constantly repeats them (Tilikina, 2020, p. 20).

Bullying occurs when there is an imbalance of power between people. An imbalance can mean that one student is older, belongs to another race, is smarter or has more friends than the other one.

It is worth noting that bullying in the educational environment occurs not only between students. A specific problem in the educational environment is bullying by teachers towards students or parents.

Such bullying can be manifest through systematic actions: unjustified underestimation of grades, systematic ignoring of the student's opinion or actions, labeling of students, derogatory words, intimidation. The object of such kind of bullying can be the whole class or group, and sometimes students are bullied by several teachers at once. This form of teacher behavior can be followed by other students, which grows into a collective bullying of the victim.
Bullying develops according to a certain scheme and has several phases of development, which can be depicted as the "ladder of bullying".

Each step of this ladder corresponds to a certain stage of bullying development, the emotional state of the victim and certain actions of the offender.

The initial phase of bullying is the emergence of a bullying community. In this phase, the target of bullying is identified (1), i.e. a student, who differs from the others. One of the reasons for the initial bullying can be weak social skills and abilities of children, when they do not know how to agree, ask for help, share thoughts or worries, and recognize their own feelings or states of other children through facial expressions, gestures, intonation. It is important that the formation of bullying requires the approval or tacit support of the bully's actions by the others - the observers.

The involvement of observers in harassment forms a so-called "bullying circle", which deepens bullying, reducing empathy for the victim under group pressure (suppression of empathy) and worsening the victim's condition.

The next stage is a quarrel or a conflict (2). There are isolated phenomena in the classroom, after which things return to normal. Some time later similar cases are repeated in the classroom - the repetition of violent actions (3), when it becomes apparent how power is distributed among students in the class. As a result, there is self-defense of the parties to bullying (harassment) (4). Regardless of the role of each participant in bullying, everyone tries to protect himself: the offender - by attacks, the victim by introversion, escape from reality, demonstration of passive behavior; he does not resist attacks and bullying. The lack of resistance of the victim occurs due to the weak development of social skills that makes it convenient for the attacker to implement distorted ways of self-affirmation through domination and humiliation.

The second phase is the phase of bullying itself. This phase includes, first of all, intentional (conscious) threats from the offender (5) increasing attacks towards one student. Any opportunity to mock is used. Secondly, there is a growing insecurity of the victim, when he (she) is feeling more and more insecure. There is a "crisis" of the victim after the second phase of bullying, when the student, who have been bullied, stop resisting; then the third phase of 
bullying occurs - the peak one. In this phase, the status of the victim is associated with the student, and self-flagellation takes place. The victim is isolated (7); bullying changes from active to passive, i.e. the manifestations of bullying become less noticeable.

The next stage is self-destruction of the victim (8); the situation in the class (group) looks calm outwardly; there are no obvious conflicts or quarrels, but the victim of bullying develops long-term stress.

The fourth phase of bullying is the highest phase, when the exclusion of the victim (9) from school team begins; the victim can start to miss classes. At this stage, the abuser pursues only one goal - to make his (her) victim to leave the class (group) or an educational institution. The consequence of this is the illness of the victim (10), which is most often manifested in mental disorders, anxiety, physical illness of psychosomatic origin, etc. However, bullying can take place according to another scheme - by excluding certain stages of this process. Interference or interruption of this process is possible at any of the stages, so it is important to recognize bullying in time and stop this process in the early stages before situation has not reached the highest one (Tilikina 2020, p. $14-16)$.

There is another concept - mobbing, which is interpreted in different ways. The proponents of the first approach consider mobbing to be less radical than bullying (obscene jokes and gossip). The proponents of the second approach consider that mobbing is group actions, while the term "bullying", according to their opinion, can be used in relation to attacks of any kind (Lane 2001, p. 57).

Mobbing can be performed not only in relation to the participants in the educational process, but also in the workplace.

There have been cases where employees knowingly damaged their victim's property, threw away his (her) documents, hid things, damaged equipment, deleted files, physically or sexually harassed him (her) during working and non-working hours (including by phone). Often the victims of mobbing are young professionals who have just come to work in a new team. Employees of pre-retirement age can become the same victims. Mobbing occurs not only in the private sector, but also in the public sector. It was found that the more years of public service, the greater the risk of mobbing by the immediate supervisor, which often manifests itself as excessive workload and / or assignment of tasks that do not meet the level of competence. Besides, the supervisor is more likely to use mobbing on women than on men.

There are the following types of mobbing:

1) Vertical mobbing - the collective is at war against the leader, or the boss bullies an employee who does not like him.

2) Horizontal mobbing involves harassment of one of the employees by the other members of a team.

3) Mixed mobbing (both vertical and horizontal) - offensive words, ignoring, obscene jokes and comments, excessive meticulousness, boycotts, unwillingness to provide information, harassment in front of the whole team, denunciations, gossip.

Note that mobbing can be both conscious (intentional) and unconscious (spontaneous).

Conscious is a purposeful action that has a specific, clearly defined goal: to create such conditions for a person to make him (her) to resign from his (her) position. In this case, it is often a matter of selfish motives - to occupy someone's post, to hold on it someone from «their», to serve before the superiors.

Unconscious mobbing occurs when a person does not realize that he (she) is engaged in tampering. It's just that one of his (her) colleagues that causes constant irritation, which accumulates and just breaks out.

Mobbing can also be latent and transparent, individual and group, etc.

The individuals experiencing mobbing in the organisations have less job satisfaction and selfconfidence, feel shame and guilt as well as helplessness and despair, have lower selfrespect, are isolated in the organisation, experience deep hopelessness, are criticized in an unfair way for their efforts, lose their motivation due to unfairness and distance from the realisation of organisational objectives due to their concern and depression. Harassment at work can lead to feelings of social inferiority; diseases of the nervous system; sleep problems; nervous breakdowns; depressive states; heart attacks and even suicide. The terrible feeling of "everything is against me" destroys the human psyche, fatally affects his (her) self-esteem. The employee begins to doubt himself (herself), his (her) competence and ability to find common 
ground with other people. The most irony is that a person who is subjected to systematic harassment sometimes stubbornly refuses to leave the workplace. The struggle for the sake of struggle leads to the shifts in the psyche: the desire to win is globalized and becomes an ultimate goal. The victims of mobbing can develop suspicion on the verge of paranoia, when ordinary and even routine problems and failures in the work process begin to seem like the machinations of the enemies, and in an innocent remark seems like irony, sarcasm and hidden criticism. Exhaustion of the nervous system inevitably affects the quality of work.

Thus, at the time of dismissal, no one doubts the legitimacy of such a final. For a long time after that, a person can still be in a state of posttraumatic stress and the acquired self-doubt later can seriously harm the new job and affect the future. There are no winners in this long psychological war: the victim is exhausted and often fells ill; his (her) relatives and friends suffer. The organization, in which such situation has happened, suffers significant material and moral losses, which are losses due to reduced productivity; damaged reputation; dismissal of good professionals who, on the one hand, did not want to participate in such games, and, on the other hand, to become the next victim.

Note that sometimes people confuse conflict with bullying, which are different things. Conflict arises when there is disagreement or dissent between two or more people. Conflict between students does not always mean that it is bullying. Children at an early age learn to understand that other people may have a different opinion than their own one, but the development of the ability to perceive a different point of view takes time, and this process continues until adulthood. In the course of a conflict, each person is free to express his (her) views and there is no imbalance of power. The way the people resolve conflict makes it positive or negative one. Conflict becomes negative when a person behaves aggressively and manifests it in painful statements or actions. After that, the conflict becomes an aggressive interaction. Conflict becomes bullying only when it is repeated over and over again and there is an imbalance of power. Over time, a pattern of behavior may emerge, in which the person, who behaves aggressively, continues to do so or even exacerbates the conflict. A person targeted by aggressive conflict may feel less able to express his (her) opinion and more powerless. It is when a negative conflict can turn into bullying. School should respond to bullying and conflict in different ways.
For example, in case of a conflict, a school employee should gather students for sharing their version of events and help them to work together to resolve the situation. In case of bullying, the school principal should consider imposing progressive disciplinary measures, which are suspension or expulsion from school.

Thus, bullying always pursues a goal: to destroy, offend, demoralize, subdue, cause fear. In one case, it can be systematic verbal abuse, denigration, abuse of someone. In other case, the effects can take the form of knocking out, taking away or damaging things, humiliation, etc. These physical or verbal actions characterize the direct bullying. There is also indirect bullying, which is manifested through manipulative behavior, spreading rumors, information, exclusion of a person from communicating with a certain group of people, joint activities (hobbies), games, ignoring, boycott.

The social nature of bullying can be viewed through the prism of the causes of this phenomenon, the vast majority of which are social in nature: the presence in society of virtually uncontrolled propaganda of violence and cruelty; lack of real actions aimed at improving the well-being of the families; unsatisfactory state of work to improve the level of legal culture of citizens; lack of comprehensive propaganda of ideas of nonviolent co-existence, etc.

\section{Conclusion}

One of the priorities of every democratic state in the area of protection of human and civil rights and freedoms is the protection of life and health of an individual. The Constitution of Ukraine (Law no. 254k/96-VR, 1996) proclaims human life and health, honor and dignity, inviolability and security as the highest social value (Article 3), emphasizing that "No one shall be subjected to torture, cruel, inhuman or degrading treatment or punishment that violates his or her dignity" (Article 28). The prohibition of torture meets the requirements of international law, on the basis of which each State, including Ukraine, considers acts of torture as crime. These are, in particular, such basic international legal acts as the Universal Declaration of Human Rights (Article 5), the International Covenant on Civil and Political Rights (Article 7), the Convention for the Protection of Human Rights and Fundamental Freedoms (Article 3), etc. 
According to the World Health Organization (WHO), Ukraine ranks $4^{\text {th }}$ by the level of adolescent aggression in Europe. Russia is in first place, Albania is in second, Belarus is the $3^{\text {rd }}$ one (Ukrainian institute for the study of extremism 2017). That is why our study is more than timely.

Based on the research conducted we tried to formulate our own concepts of bulling and mobbing. Thus, in our opinion, bullying is a type of violence that has a deliberate nature, is manifested in prolonged aggression associated with repeated acts of physical, mental, economic, sexual nature by a person or group of people who have certain advantages (physical, psychological, etc.), with the possible use of technical means that are committed for a specific purpose (intimidation of the individual, punishment for an act, moral humiliation, coercion to confess to something, etc.), which causes various kinds (social, material, moral, physiological, psychological, etc.) negative consequences and is dangerous to life and health.

Mobbing is a systematic harassment, psychological terror, a form of psychological pressure as a harassment of an employee in the team, usually in order to dismiss him (her).

\section{References}

Buchner, G. (2001). Gewalt in der familie. Gewaltinfo. Available online. https://www.gewaltinfo.at/uploads/pdf/bmwfj_ gewaltbericht_2001_gesamt.pdf. date of consultation 15/01/2021.

Korol, A. (2009). "Causes and consequences of bullying". Restorative justice in ukraine, vol. 1-2, (13), pp. 84-93.

Lane, D. (2001). School harassment (bullying). child and adolescent psychotherapy. Saintpetersburg: Peter.

Law no. 254k/96-vr. Constitution of Ukraine, june 28 of 1996. Available online. https://zakon.rada.gov.ua/laws/show/254\%d0 $\%$ ba/96-\%d0\%b2\%d1\%80\#tex. date of consultation 15/01/2021.

Ministry of education and the ministry of attorney general. (1999). Focus on bullying: a prevention program for elementary school communities. Burnaby: b.c. safe school centre.
Ministry of education of ontario. (2013). Bullying - we can all help stop this. a guide for parents (in ukrainian). Queen's printer for ontario. available online. http://www.edu.gov.on.ca/eng/multi/ukrainian/ bullyinguk.pdf. date of consultation 15/01/2021.

Morozov, O. (2010). "Features of bullying and mobbing in russia". in: actual problems of aviation and astronautics, No. 6. pp. 262-263.

Olweus, D. (1993). bullying at school: what we know and what we can do. Cambridge, ma: blackwell publishers, inc.

Oudmayer, K. (2016). All for one: how to protect your child from bullying at school (translation from norvegian). Moskow: alpina publisher.

Ponomarev, V. (2013). "Research of character accentuations of bullying participants in the adolescents contingent of a regional social institution for minors". World of medicine and biology, vol. 3, num. 39, pp. $125-130$.

Randall, P. (2001). Bullying in adulthood. assessing the bullies and their victims (1st ed.). London: https://doi.org/10.4324/9780203469224

Sampson, R. (2009). Bullying in schools. problem-oriented guides for police problemspecific guides series guide no. 12. University of Nebraska Lincoln. Available online. https://digitalcommons.unl.edu/usjusticematls/ 6/. date of consultation 15/01/2021.

Tilikina, N. (2020). About bullying and how to overcome it. about important for children, young people and adults. Kyiv: State institute of family and youth policy.

Ukrainian institute for the study of extremism. (2017). Research "stop school terror. prevention and counteraction to bullying". available online. http://uire.org.ua/wpcontent/uploads/2017/11/doslidzhennyabuling.pdf. date of consultation 15/01/2021. Zhebrova, A. (2016). Bullying as a form of torture among minors. Available online. http://www.nusta.edu.ua/wp-

content/uploads/2016/11/\%D0\%96\%D0\%B5\% D0\%B1\%D1\%80\%D0\%BE\%D0\%B2\%D0\%B 0 -

$\% \mathrm{D} 0 \% 90 \% \mathrm{D} 0 \% \mathrm{BD} \% \mathrm{D} 0 \% \mathrm{~B} 0 \% \mathrm{D} 1 \% 81 \% \mathrm{D} 1 \%$ $82 \% \mathrm{D} 0 \% \mathrm{~B} 0 \% \mathrm{D} 1 \% 81 \% \mathrm{D} 1 \% 96 \% \mathrm{D} 1 \% 8 \mathrm{~F}-$ $\% \mathrm{D} 0 \% 9 \mathrm{E} \% \mathrm{D} 0 \% \mathrm{BB} \% \mathrm{D} 0 \% \mathrm{~B} 5 \% \mathrm{D} 0 \% \mathrm{BA} \% \mathrm{D} 1$ $\% 81 \% \mathrm{D} 0 \% \mathrm{~B} 0 \% \mathrm{D} 0 \% \mathrm{BD} \% \mathrm{D} 0 \% \mathrm{~B} 4 \% \mathrm{D} 1 \% 80 \%$ D1\%96\%D0\%B2\%D0\%BD\%D0\%B0.pdf. Date of consultation 15/01/2021. 